\title{
26. PALEOCEANOGRAPHIC CONDITIONS FOLLOWING THE EARLIEST PLIOCENE FLOODING OF THE TYRRHENIAN SEA ${ }^{1}$
}

\author{
Judith A. McKenzie² and Rodolfo Sprovieri ${ }^{3}$
}

\begin{abstract}
High-resolution bio- and chemostratigraphy of an earliest Pliocene section from ODP Site 652 indicates that postflood paleoceanographic conditions in the Tyrrhenian Sea can be sub-divided into two discrete intervals. The first is manifested by an acme of Sphaeroidinellopsis spp., increasing carbonate contents, and a progressive decrease upsection in both the $\delta^{13} \mathrm{C}$ and $\delta^{18} \mathrm{O}$ values of the planktonic foraminifera. The lower part of the acme interval contains unusual surface-to-bottom water isotope gradients suggesting a stratification of two water masses. Normal gradients in the upper part of the acme interval suggest a well-mixed water body. Between the end of the acme interval and the MPI1/MPI2 boundary, denoted by the first occurrence (F.O.) of Globorotalia margaritae, a migrational first appearance, there was a catastrophic collapse of the gradient marking an onset of the second post-flood interval. The disintegration of habitable conditions is suggested by a sharp decrease in carbonate content and the disappearance of the benthonic assemblage, which is subsequently replaced predominantly by Uvigerina pygmea, indicative of cold, low-oxygenated bottom waters. The introduction of benthonic species denoting well-oxygenated bottom conditions occurs within the lower MPI2 zone. Superimposed on these overall trends are shorter term, warm-cold cycles, which are interpreted as orbitally induced, climatic fluctuations. Correlative studies of the less complete earliest Pliocene sections from ODP Holes 653B and 654A confirm these interpretations.

A scenario derived from an integration of all the stratigraphic data indicates that normal paleoceanographic conditions were operating in the Tyrrhenian Sea only approximately $250,000 \mathrm{yr}$ after the cessation of Messinian evaporative conditions at the Miocene/Pliocene boundary. The post-flood interval is marked by an initial period of gradual infilling, the Sphaeroidinellopsis spp. acme interval, followed by a disintegration of oceanographic conditions and a second recovery period. A sudden influx of cold, deep Atlantic waters into the Tyrrhenian Sea, resulting from a major tectonic break in the Gibraltar sill, may have caused this catastrophic reversal in the orderly recovery of normal paleoceanographic conditions in the post-flood period.
\end{abstract}

\section{INTRODUCTION}

The desiccation of the Mediterranean during the late Messinian was undoubtedly a noteworthy geological event. The termination of this salinity crisis with the earliest Pliocene (Zanclean) marine flooding of the evaporative basins must have been equally significant. In the field and in drill core, the notable lithologic contact between evaporitic and pelagic sediments, which denotes the Miocene/Pliocene boundary, strongly implies a geologically sudden change in environmental conditions. Because the pelagic ooze unconformably overlies the evaporites, the earliest Pliocene (MPl1 biozone) is frequently missing or reduced in many Miocene/Pliocene boundary sections. To evaluate the paleoceanographic conditions occurring after the onset of marine flooding, it is obviously crucial to study the most complete sections containing the very earliest Pliocene sediments.

During ODP Leg 107 at Site 652 in the Tyrrhenian Sea, an apparently complete MPl1 biozone was recovered within Core 20R (Shipboard Scientific Party, 1987a). The latest Messinian sediments were dolomitic-calcareous muds deposited subaqueously in a lacustrine environment. A $40-\mathrm{cm}$ interval transitional between the latest Miocene lacustrine and earliest Pliocene marine sediments was recovered. This sedimentary sequence suggests that subaqueous conditions persisted across the Miocene/Pliocene boundary promoting what appears to have been continuous sedimentation. This fortuitous recovery offered the opportunity to investigate the paleoceanographic changes during and

\footnotetext{
${ }^{1}$ Kastens, K. A., Mascle, J., et al., 1990. Proc. ODP, Sci. Results, 107: College Station, TX (Ocean Drilling Program).

2 Geological Institute, ETH-Zentrum, 8092 Zurich, Switzerland.

${ }^{3}$ Istituto di Geologia, Corso Turkory, 131, 90100 Palermo, Italy.
}

directly after the infilling of the Mediterranean in the earliest Pliocene.

This paper presents the results of a high-resolution bio- and chemostratigraphic analysis of early Pliocene (MP11 to basal MPI2) sediments recovered at ODP Site 652. The Miocene/Pliocene boundary was also cored at ODP Holes 653B and 654A, which are likewise located on the eastern continental margin of Sardinia but at shallower depths (Fig. 1) (Shipboard Scientific Party, 1987b, c). The contact at these latter two sites was not recovered and, in comparison with Site 652 , a significant portion of the earliest Pliocene is apparently missing. For comparative purposes, we analyzed the available MPl1 to basal MPl2 sediments from Holes 653B and 654A.

\section{METHODOLOGY}

High-resolution sampling was done on-board the JOIDES Resolution at closely spaced intervals of approximately $50-70 \mathrm{~cm}$ throughout the MPI1 and into the basal MPI2 biozones, as determined by the micropaleontologists. For this shore-based study, the samples $\left(10 \mathrm{~cm}^{3}\right)$ were washed on $62-\mu \mathrm{m}$ sieves and the residues larger than $125 \mu \mathrm{m}$ were studied for the micropaleontologic analysis. For the planktonic foraminifera analysis, at least 300 specimens were counted in order to achieve a statistically significant distribution pattern. Samples of approximately 10-20 specimens of Globigerinoides obliquus and 3-10 specimens of Oridorsalis stellatus and Uvigerina peregrina were hand-picked for stable isotope analyses, which were made using a Finnigan-Mat 251 mass spectrometer at the Stable Isotope Laboratory of the Rosenstiel School of Marine and Atmospheric Science, University of Miami. Oxygen and carbon isotope measurements were run on $\mathrm{CO}_{2}$ gas produced using a modified method of dissolution in phosphoric acid at $50^{\circ} \mathrm{C}$ (McCrea, 1950; Wachter and Hayes, 1985). The isotope data, corrected following the procedure of Craig (1957) modified for a triple collector, are given in Table 1 relative to the international standard Peedee Belemnite (PDB). The percent carbonate in bulk samples was measured using a combustion-titration apparatus, Coulometrics System 140 at the Florida State Museum, University of Florida. The values are given in Table 2. 

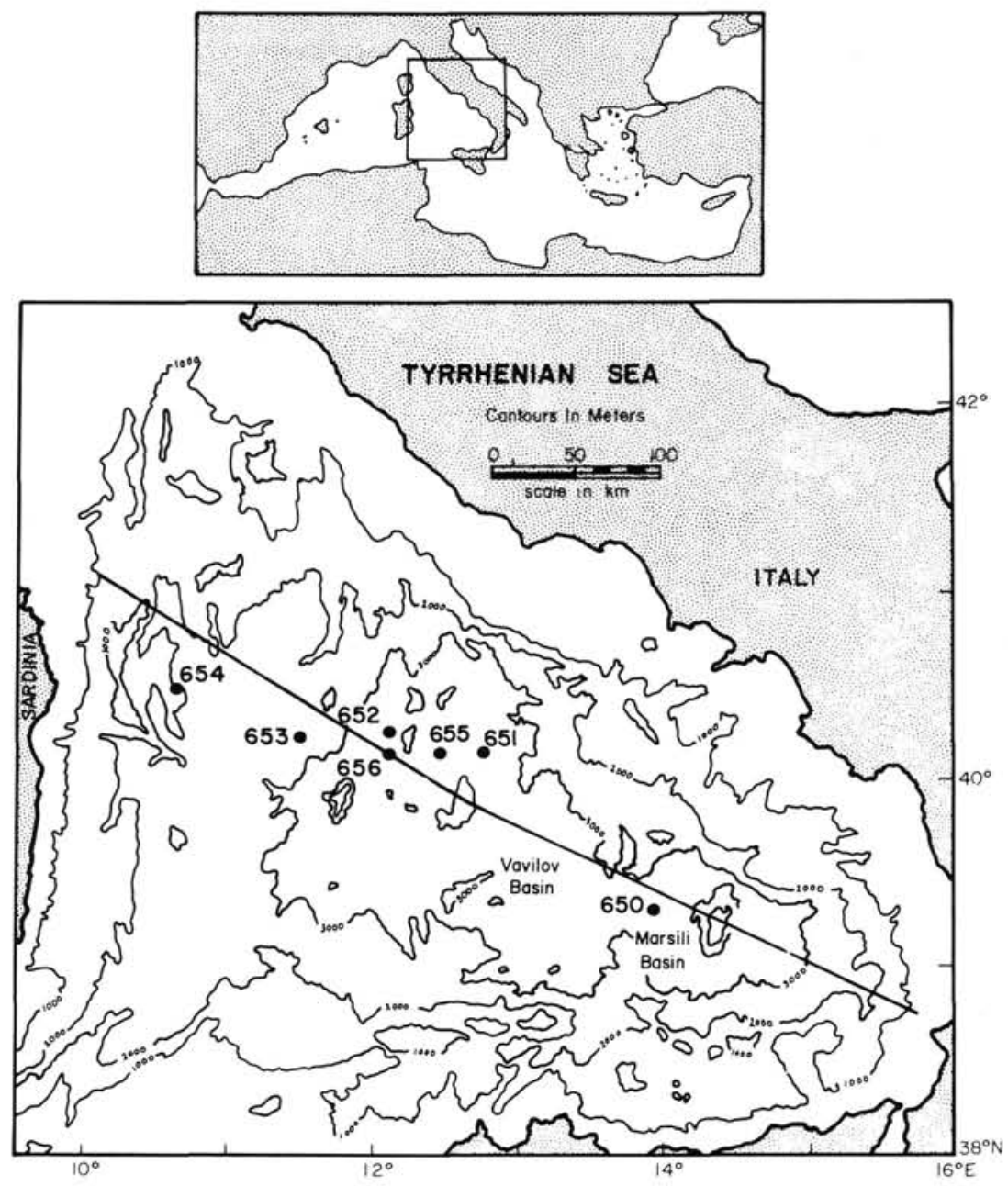

Figure 1. Map of the Tyrrhenian Sea showing the locations of ODP Leg 107 Sites 652, 653, and 654 , where sediments across the Miocene/Pliocene boundary were cored.

\section{BIOSTRATIGRAPHY OF THE EARLIEST PLIOCENE MEDITERRANEAN}

\section{Planktonic Foraminifera}

The Miocene/Pliocene boundary in the Mediterranean region is distinguished by a sharp lithostratigraphic change from evaporites or continental deposits to pelagic marine marls. The first foraminifera biozone in the earliest Mediterranean Pliocene (MPI1) is recognized by an acme of Sphaeroidinellopsis spp. The acme ends prior to the beginning of the MPl2 biozone, which is defined by the first occurrence (F.O.) of Globorotalia margaritae (Cita and Gartner, 1973).

The biostratigraphic data essential for this study of the earliest Pliocene sediments recovered during ODP Leg 107 are summarized from Glaçon et al. (this volume). At Site 652, the base of the Pliocene is at 188.1 mbsf, the top of the Sphaeroidinellopsis acme is at $178.5 \mathrm{mbsf}$ and the F.O. Globorotalia margaritae is at 176.5 mbsf. The MPL1 zone is thus about $11.6 \mathrm{~m}$ thick. At Hole 653B, the Pliocene begins in Core $23 \mathrm{X}-\mathrm{CC}$ at about 213.7 mbsf. The top of the acme is at $211.5 \mathrm{mbsf}$, and the MPl1/MPI2 boundary is at 209 mbsf. The minimum thickness of the MPl1 zone is $4.7 \mathrm{~m}$. For Hole 654A, the acme ends at 238.8 mbsf and Globorotalia margaritae first appears at 236.4 mbsf. The oldest Pliocene is found in Core 26R-CC at about 239.6 mbsf, giving a minimum recovery of $3.2 \mathrm{~m}$ of MPl1 sediments. As mentioned previously, the MPIl zone at Site 652 is by the far the most complete. For Holes 653B and 654A, either recovery was poor or part of the earliest Pliocene is simply missing at these locations. The recognition of these datum levels allows for inter-correlation among the three sites.

Abundances of specific foraminifera were used to evaluate climatic cycles in the earliest Pliocene. The specific counts are normalized to $100 \%$, and these percentages are plotted against depth for each of the three sites (Figs. 2, 3, and 4). Synchronous, but complementary fluctuations in the relative abundances of total Globigerinoides spp, representing warmer waters, vs. Globigerina bulloides (s.l.), indicating colder waters, are particularly noteworthy. For the more complete earliest Pliocene section at Site 652 , seven discrete warm intervals were noted between 188 and 165 mbsf from the base of MPl1 into the lower part of MPI2 (Fig. 2). The warm-cold cycles begin with warmer waters at the very base of MPl1 zone. Warmer intervals alternating with colder periods are likewise reflected in the oxygen-isotope data, which are discussed below. Using the depths for the end of the Sphaeroidinellopsis acme and the F.O. Globorotalia margaritae as correlation levels, the lower two warm periods are apparently missing at Hole 653B, as are the lower three at Site 654, confirming further the incompleteness of these MPl1 zones (Figs. 3 and 4).

Based on the available magnetostratigraphic data for Site 652 (Shipboard Scientific Party, 1987a), the lowest normal polarity (Thvera or C2 interval) of the Gilbert chron spans be- 
Table 1. Stable isotope data.

\begin{tabular}{lccc}
\hline Sample number & $\begin{array}{c}\text { Depth } \\
\text { (mbsf) }\end{array}$ & $\begin{array}{c}\delta^{18} \mathrm{O} \\
\text { (PDB \%o) }\end{array}$ & $\begin{array}{c}\delta^{13} \mathrm{C} \\
\text { (PDB \%o) }\end{array}$ \\
\hline Hole 652A-Globigerinoides obliquus \\
18R-3, 6-8 cm & 163.9 & -1.30 & +1.67 \\
18R-3, 101-103 cm & 164.8 & -0.42 & +1.57 \\
18R-4, 101-103 cm & 166.3 & -0.37 & +1.17 \\
18R-5, 6-8 cm & 166.9 & -0.71 & +1.71 \\
18R-6, 6-8 cm & 168.4 & -0.52 & +1.51 \\
18R-6, 101-103 cm & 169.3 & -1.47 & +1.39 \\
19R-1, 91-93 cm & 171.4 & -1.06 & +1.61 \\
19R-2, 18-20 cm & 172.0 & -0.97 & +1.13 \\
19R-2, 91-93 cm & 172.9 & -1.87 & +1.77 \\
19R-3, 18-20 cm & 173.7 & -1.35 & +1.72 \\
19R-3, 91-93 cm & 174.4 & -0.03 & +1.83 \\
19R-4, 18-20 cm & 175.2 & -1.37 & +1.48 \\
19R-5, 18-20 cm & 176.7 & -0.94 & +0.59 \\
19R-5, 91-93 cm & 177.4 & -0.64 & +0.12 \\
19R-6, 18-20 cm & 178.2 & -1.22 & +1.48 \\
19R-6, 91-93 cm & 178.9 & -2.12 & -0.29 \\
19R, CC & 179.3 & -1.10 & +0.49 \\
20R-1, 12-14 cm & 180.3 & -0.93 & +0.81 \\
20R-1, 94-96 cm & 181.2 & -1.24 & +0.12 \\
20R-2, 5-7 cm & 181.8 & -0.64 & +0.83 \\
20R-2, 94-96 cm & 182.6 & -0.93 & +0.46 \\
20R-3, 12-14 cm & 183.3 & -0.77 & +0.91 \\
20R-3, 94-96 cm & 184.2 & +0.47 & +1.35 \\
20R-4, 12-14 cm & 184.8 & +0.20 & +1.02 \\
20R-4, 94-96 cm & 185.6 & -0.17 & +1.04 \\
20R-5, 24-25 cm & 186.4 & +0.49 & +1.72 \\
20R-5, 94-96 cm & 187.2 & +1.36 & +1.89 \\
20R-6, 16-17 cm & 187.9 & +0.59 & +1.78 \\
20R-6, 45-46 cm & 188.2 & +0.74 & +1.58 \\
& & &
\end{tabular}

Hole 652A-Oridorsalis stellatus

$\begin{array}{llll}18 \mathrm{R}-3,6-8 \mathrm{~cm} & 163.9 & +1.24 & -0.50 \\ 18 \mathrm{R}-4,6-8 \mathrm{~cm} & 165.4 & +1.08 & -0.37 \\ 18 \mathrm{R}-4,101-103 \mathrm{~cm} & 166.3 & +1.04 & -0.44 \\ 18 \mathrm{R}-5,6-8 \mathrm{~cm} & 166.9 & +1.20 & -0.42 \\ 18 \mathrm{R}-6,6-8 \mathrm{~cm} & 168.4 & +0.86 & -0.65 \\ 18 \mathrm{R}-6,101-103 \mathrm{~cm} & 169.3 & +0.66 & -1.05 \\ 19 \mathrm{R}-1,16-18 \mathrm{~cm} & 170.5 & +0.12 & -0.86 \\ 19 \mathrm{R}-3,18-20 \mathrm{~cm} & 173.7 & +1.40 & -0.13 \\ 19 \mathrm{R}-5,18-20 \mathrm{~cm} & 176.7 & -1.95 & -3.62 \\ 19 \mathrm{R}, \mathrm{CC} & 179.3 & +0.48 & -2.83 \\ 20 \mathrm{R}-1,94-96 \mathrm{~cm} & 181.2 & +0.64 & -2.11 \\ 20 \mathrm{R}-2,94-96 \mathrm{~cm} & 182.6 & +0.62 & -1.77 \\ \text { 20R-3, 94-96 cm } & 184.2 & -1.93 & -3.82 \\ \text { 20R-4, 94-96 cm } & 185.6 & -2.18 & -4.81\end{array}$

Hole 653B-Globigerinoides obliquus

$\begin{array}{llrr}23 X-1,15-17 \mathrm{~cm} & 206.9 & -0.94 & +0.67 \\ 23 X-1,75-77 \mathrm{~cm} & 207.5 & -1.53 & +3.19 \\ 23 X-1,146-148 \mathrm{~cm} & 208.1 & -1.87 & +2.95 \\ 23 X-2,15-17 \mathrm{~cm} & 208.4 & -0.66 & +1.59 \\ 23 X-2,75-77 \mathrm{~cm} & 209.0 & -1.38 & +3.49 \\ 23 X-2,146-148 \mathrm{~cm} & 209.6 & -2.30 & +3.12 \\ 23 X-3,15-17 \mathrm{~cm} & 210.0 & -1.98 & +0.84 \\ 23 X-3,75-77 \mathrm{~cm} & 210.5 & +0.56 & +1.57 \\ 23 X-4,15-17 \mathrm{~cm} & 211.4 & -1.34 & +1.42 \\ 23 X-4,75-77 \mathrm{~cm} & 212.0 & -1.16 & +2.87 \\ 23 X-4,146-148 \mathrm{~cm} & 212.6 & -1.34 & +3.04 \\ 23 X-5,15-17 \mathrm{~cm} & 212.9 & -0.95 & +1.54 \\ 23 X-5,75-77 \mathrm{~cm} & 213.5 & -0.90 & +2.90 \\ 23 X, C C & 213.7 & -1.27 & +0.98\end{array}$

Hole 653B-Oridorsalis stellatus

$\begin{array}{llll}23 \mathrm{X}-1,15-17 \mathrm{~cm} & 206.9 & +0.42 & -1.32 \\ 23 \mathrm{X}-1,146-148 \mathrm{~cm} & 208.1 & -0.04 & +0.78 \\ 23 \mathrm{X}-2,15-17 \mathrm{~cm} & 208.4 & +0.84 & -0.78 \\ 23 \mathrm{X}-2,75-77 \mathrm{~cm} & 209.0 & +0.81 & -1.09 \\ 23 \mathrm{X}-2,146-148 \mathrm{~cm} & 209.6 & +0.82 & -1.53 \\ 23 \mathrm{X}-4,15-17 \mathrm{~cm} & 211.4 & +0.57 & -0.77 \\ 23 \mathrm{X}-5,15-17 \mathrm{~cm} & 212.9 & +0.00 & -0.83 \\ 23 \mathrm{X}-5,75-77 \mathrm{~cm} & 213.5 & +0.13 & - \\ 23 X, \mathrm{CC} & 213.7 & +0.09 & +0.65\end{array}$

Table 1 (continued).

\begin{tabular}{|c|c|c|c|}
\hline Sample number & $\begin{array}{l}\text { Depth } \\
\text { (mbsf) }\end{array}$ & $\begin{array}{c}\delta^{18} \mathrm{O} \\
\left(\mathrm{PDB} \%_{0}\right)\end{array}$ & $\begin{array}{c}\delta^{13} \mathrm{C} \\
\left(\mathrm{PDB} \%_{0}\right)\end{array}$ \\
\hline \multicolumn{4}{|c|}{ Hole $654 \mathrm{~A}-$ Globigerinoides obliquus } \\
\hline $25 \mathrm{R}-3,70-72 \mathrm{~cm}$ & 226.8 & -0.96 & +1.29 \\
\hline $25 \mathrm{R}-4,10-12 \mathrm{~cm}$ & 227.7 & -1.34 & +1.50 \\
\hline $25 \mathrm{R}-4,70-72 \mathrm{~cm}$ & 228.3 & +0.04 & +1.47 \\
\hline $25 \mathrm{R}-5,10-12 \mathrm{~cm}$ & 229.2 & -0.67 & +1.62 \\
\hline $25 \mathrm{R}-5,70-72 \mathrm{~cm}$ & 229.8 & +0.04 & +1.41 \\
\hline $26 \mathrm{R}-1,10-12 \mathrm{~cm}$ & 232.8 & -1.71 & +1.37 \\
\hline $26 \mathrm{R}-1,70-71 \mathrm{~cm}$ & 233.4 & -0.49 & +1.30 \\
\hline $26 \mathrm{R}-2,10-12 \mathrm{~cm}$ & 234.3 & -0.19 & +0.96 \\
\hline $26 \mathrm{R}-2,70-71 \mathrm{~cm}$ & 234.9 & -0.36 & +1.22 \\
\hline $26 \mathrm{R}-3,10-12 \mathrm{~cm}$ & 235.8 & 0.00 & +1.04 \\
\hline $26 \mathrm{R}-3,70-71 \mathrm{~cm}$ & 236.4 & -0.54 & +1.12 \\
\hline $26 \mathrm{R}-4,10-12 \mathrm{~cm}$ & 237.3 & -2.40 & +1.94 \\
\hline $26 \mathrm{R}-4,70-71 \mathrm{~cm}$ & 237.9 & -0.80 & +1.46 \\
\hline $26 \mathrm{R}-5,10-12 \mathrm{~cm}$ & 238.8 & -1.21 & +1.40 \\
\hline \multicolumn{4}{|c|}{ Hole $654 \mathrm{~A}-$ Oridorsalis stellatus } \\
\hline $25 \mathrm{R}-3,70-72 \mathrm{~cm}$ & 226.8 & -0.25 & -1.64 \\
\hline $25 \mathrm{R}-4,10-12 \mathrm{~cm}$ & 227.1 & +1.03 & -0.47 \\
\hline $25 \mathrm{R}-4,70-72 \mathrm{~cm}$ & 228.3 & +1.62 & -0.62 \\
\hline $25 \mathrm{R}-5,10-12 \mathrm{~cm}$ & 229.2 & +1.22 & -0.06 \\
\hline $26 \mathrm{R}-1,70-71 \mathrm{~cm}$ & 233.4 & +1.47 & -0.44 \\
\hline \multicolumn{4}{|c|}{ Hole $654 \mathrm{~A}-$ Uvigerina peregrina } \\
\hline $26 \mathrm{R}-1,70-71 \mathrm{~cm}$ & 233.4 & +1.21 & -0.77 \\
\hline $26 \mathrm{R}-2,10-12 \mathrm{~cm}$ & 234.3 & +1.19 & -1.14 \\
\hline $26 \mathrm{R}-2,70-71 \mathrm{~cm}$ & 234.9 & +1.08 & -0.98 \\
\hline $26 \mathrm{R}-3,10-12 \mathrm{~cm}$ & 235.8 & +0.15 & -1.32 \\
\hline $26 \mathrm{R}-5,10-12 \mathrm{~cm}$ & 238.8 & +1.19 & -0.96 \\
\hline
\end{tabular}

tween 167.2 and $182.1 \mathrm{mbsf}$ and contains approximately four complete, warm-cold-warm cycles. The underlying reversed polarity interval contains two complete cycles between $182 \mathrm{mbsf}$ and the Miocene/Pliocene boundary at $188 \mathrm{mbsf}$. Using the time scale of Berggren et al. (1985), the top of the Thvera (C2) interval has an age of $4.57 \mathrm{Ma}$, while the strontium-isotope age for the Miocene/Pliocene boundary stratotype section in Sicily is $4.9 \mathrm{Ma}$ (McKenzie et al., 1988). The average cycle, thus, lasted $63,000 \mathrm{yr}$. This duration is comparable to one of the late Pleistocene Milankovitch climatic cycles. For example, oxygenisotope stage $5 \mathrm{e}$ of the deep sea record is dated at $125,000 \mathrm{yr}$ B.P. (Broecker et al., 1968). The average duration of the two warm-cold-warm intervals between isotope stage 5e and 1 (i.e., warm events 1,3 , and 5 and intervening cold events 2 and 4) would be $62,500 \mathrm{yr} /$ cycle. Thus, it is conceivable that the variations in planktonic foraminiferal abundances between warm and cold water species are a reflection of orbitally induced climatic cycles. The oxygen-isotope data are in agreement with this conclusion.

\section{Benthonic Foraminifera}

At Site 652 , benthonic foraminifera are unfortunately very rare, particularly at the very base of the Pliocene. No benthics were found at $188 \mathrm{mbsf}(652 \mathrm{~A}-20 \mathrm{R}-6,45 \mathrm{~cm})$. Between 187 and $185.44 \mathrm{mbsf}$, only Oridorsalis stellatus is present. Above, the assemblage is expanded to include Globocassidulina subglobosa and Gyroidinoides neosoldanii, but both species disappear at 178.46 mbsf (652A-19R-6, $91 \mathrm{~cm}$ ). In the interval from 176.97 mbsf $(652 \mathrm{~A}-19 \mathrm{R}-5,91 \mathrm{~cm})$ to $173.95 \mathrm{mbsf}(652 \mathrm{~A}-19 \mathrm{R}-3,91 \mathrm{~cm})$, i.e., above the end of Sphaeroidinellopsis spp. acme to the basal part of MP12, Uvigerina pygmaea (or U. peregrina), indicative of abnormally low oxygen levels, is consistently present $(4 \%-$ $64 \%$ ) together with $O$. stellatus. Above $174 \mathrm{mbsf}, U$. pygmaea disappears and species generally indicative of "normal" or oxy- 
Table 2. Percent carbonate data.

\begin{tabular}{|c|c|c|}
\hline Sample number & $\begin{array}{l}\text { Depth } \\
\text { (mbsf) }\end{array}$ & $\begin{array}{c}\text { Carbonate } \\
(\%)\end{array}$ \\
\hline \multicolumn{3}{|l|}{ Hole $652 \mathrm{~A}$ - } \\
\hline $19 \mathrm{R}-3,101-103 \mathrm{~cm}$ & 174.5 & 50.6 \\
\hline $19 \mathrm{R}-3,140-142 \mathrm{~cm}$ & 174.9 & 57.5 \\
\hline $19 \mathrm{R}-4,17-19 \mathrm{~cm}$ & 175.2 & 48.5 \\
\hline $19 \mathrm{R}-4,98-100 \mathrm{~cm}$ & 176.0 & 56.0 \\
\hline 19R-5, 87-89 cm & 177.4 & 42.9 \\
\hline $19 \mathrm{R}-6,9-11 \mathrm{~cm}$ & 178.1 & 49.0 \\
\hline 19R-6, 96-98 cm & 179.0 & 55.3 \\
\hline $19 \mathrm{R}-6,134-136 \mathrm{~cm}$ & 179.3 & 58.1 \\
\hline $20 \mathrm{R}-1,28-30 \mathrm{~cm}$ & 180.5 & 56.1 \\
\hline $20 \mathrm{R}-1,80-82 \mathrm{~cm}$ & 181.0 & 52.6 \\
\hline $20 \mathrm{R}-1,129-131 \mathrm{~cm}$ & 181.5 & 52.0 \\
\hline $20 \mathrm{R}-2,28-30 \mathrm{~cm}$ & 182.0 & 52.2 \\
\hline $20 \mathrm{R}-2,79-81 \mathrm{~cm}$ & 182.5 & 57.4 \\
\hline $20 \mathrm{R}-2,129-131 \mathrm{~cm}$ & 183.0 & 51.5 \\
\hline $20 \mathrm{R}-3,30-32 \mathrm{~cm}$ & 183.5 & 55.6 \\
\hline $20 \mathrm{R}-3,80-82 \mathrm{~cm}$ & 184.0 & 57.0 \\
\hline $20 \mathrm{R}-3,130-132 \mathrm{~cm}$ & 184.5 & 49.9 \\
\hline $20 \mathrm{R}-4,27-29 \mathrm{~cm}$ & 185.0 & 52.4 \\
\hline $20 \mathrm{R}-4,78-80 \mathrm{~cm}$ & 185.5 & 54.5 \\
\hline $20 \mathrm{R}-4,128-130 \mathrm{~cm}$ & 186.0 & 51.4 \\
\hline $20 \mathrm{R}-5,30-32 \mathrm{~cm}$ & 186.5 & 55.5 \\
\hline $20 \mathrm{R}-5,79-81 \mathrm{~cm}$ & 187.0 & 46.9 \\
\hline $20 \mathrm{R}-5,129-131 \mathrm{~cm}$ & 187.5 & 50.7 \\
\hline $20 \mathrm{R}-6,10-11 \mathrm{~cm}$ & 187.8 & 32.1 \\
\hline $20 \mathrm{R}-6,20-21 \mathrm{~cm}$ & 187.9 & 47.1 \\
\hline $20 \mathrm{R}-6,30-31 \mathrm{~cm}$ & 188.0 & 55.1 \\
\hline $20 \mathrm{R}-6,40-41 \mathrm{~cm}$ & 188.1 & 35.1 \\
\hline \multicolumn{3}{|l|}{ Hole 653B- } \\
\hline $23 \mathrm{X}-1,50-52 \mathrm{~cm}$ & 207.2 & 53.8 \\
\hline $23 \mathrm{X}-2,50-52 \mathrm{~cm}$ & 208.7 & 64.9 \\
\hline $23 \mathrm{X}-2,126-128 \mathrm{~cm}$ & 209.5 & 52.9 \\
\hline $23 \mathrm{X}-3,50-52 \mathrm{~cm}$ & 210.2 & 51.8 \\
\hline $23 \mathrm{X}-3,126-128 \mathrm{~cm}$ & 211.0 & 45.2 \\
\hline $23 \mathrm{X}-4,50-52 \mathrm{~cm}$ & 211.7 & 59.3 \\
\hline $23 \mathrm{X}-4,126-128 \mathrm{~cm}$ & 212.5 & 70.0 \\
\hline $23 \mathrm{X}-5,50-52 \mathrm{~cm}$ & 213.2 & 61.7 \\
\hline $23 \mathrm{X}-5,96-98 \mathrm{~cm}$ & 213.7 & 56.0 \\
\hline \multicolumn{3}{|l|}{ Hole 654A- } \\
\hline $25 \mathrm{R}-4,133-135 \mathrm{~cm}$ & 228.9 & 64.9 \\
\hline $25 \mathrm{R}-5,24-26 \mathrm{~cm}$ & 229.3 & 61.5 \\
\hline $25 \mathrm{R}-5,135-137 \mathrm{~cm}$ & 230.4 & 60.1 \\
\hline $26 \mathrm{R}-1,81-83 \mathrm{~cm}$ & 233.5 & 54.5 \\
\hline $26 \mathrm{R}-2,22-24 \mathrm{~cm}$ & 234.4 & 52.6 \\
\hline $26 \mathrm{R}-2,131-133 \mathrm{~cm}$ & 235.5 & 48.9 \\
\hline $26 \mathrm{R}-3,16-18 \mathrm{~cm}$ & 235.9 & 46.7 \\
\hline $26 \mathrm{R}-3,80-82 \mathrm{~cm}$ & 236.5 & 46.7 \\
\hline $26 \mathrm{R}-3,139-141 \mathrm{~cm}$ & 237.3 & 55.2 \\
\hline $26 \mathrm{R}-4,33-35 \mathrm{~cm}$ & 237.5 & 59.4 \\
\hline $26 \mathrm{R}-5,3-5 \mathrm{~cm}$ & 238.7 & 58.4 \\
\hline $26 \mathrm{R}, \mathrm{CC}, 11-13 \mathrm{~cm}$ & 239.6 & 56.7 \\
\hline
\end{tabular}

genated bottom-water conditions, such as Parrelloides bradyi, P. robertsonianus, Martinottiella perparva, Pleurostomella alternans, and Quinqueloculina venusta, dominate.

At Holes 653A and -B, the number of benthonic species and specimens is low in the MPl1 interval (4-9 species with 10-34 specimens) and slightly increases above the MPI1/MPI2 boundary (6-15 species and 27-70 specimens). A total of 36 species was recognized but due to the relatively low number of specimens, the percent data are not very significant. In general, the trends are similar to Site 652 with species indicative of low-oxygen conditions occurring from the onset of Pliocene sedimentation to the basal part of MP12. U. pygmaea are few to abundant $(4 \%-34 \%)$ and Dentalina filiformis, G. subglobosa, Gyroidinoides laevigata, and $O$. stellatus are consistently present. Above, the benthonic assemblage suggests a change to more normal, oxygenated bottom-waters.
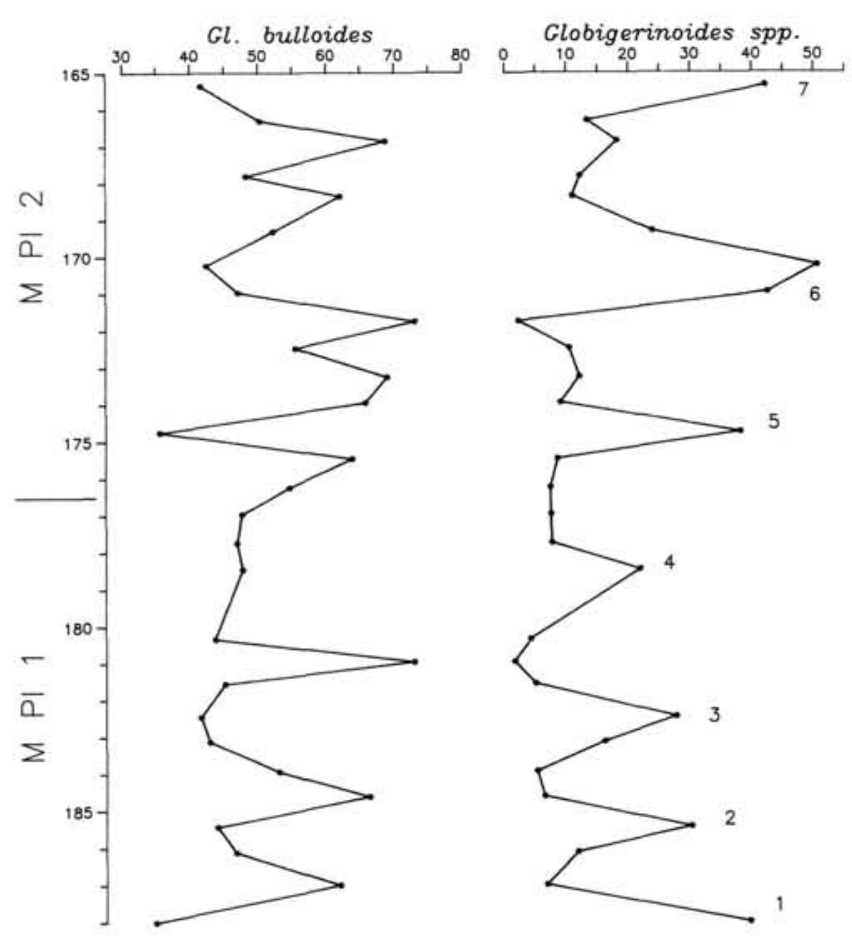

Figure 2. Graph for Hole 652A showing fluctuations with depth between warm-cold cycles, as indicated by changes in the relative percent of Globigerinoides spp. (warmer waters) vs. Globigerina bulloides (s.1.) (colder waters).

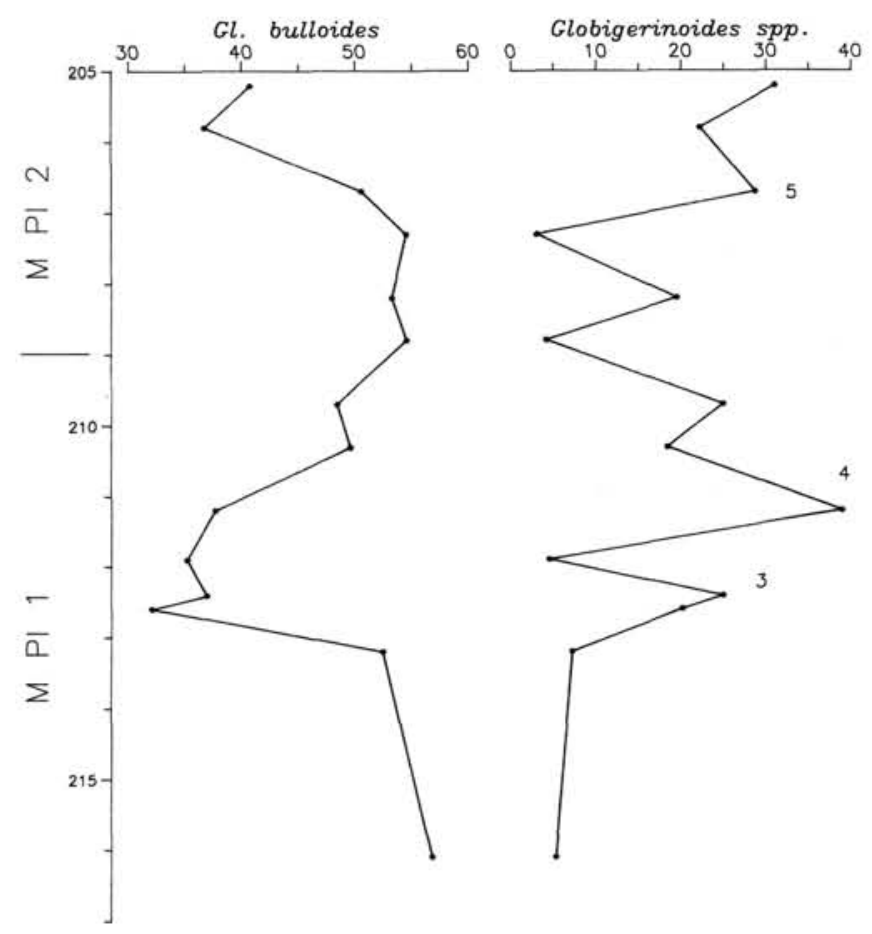

Figure 3. Graph for Hole 653B showing fluctuations with depth between warm-cold cycles, as indicated by changes in the relative percent of Globigerinoides spp. (warmer waters) vs. Globigerina bulloides (s.1.) (colder waters). 


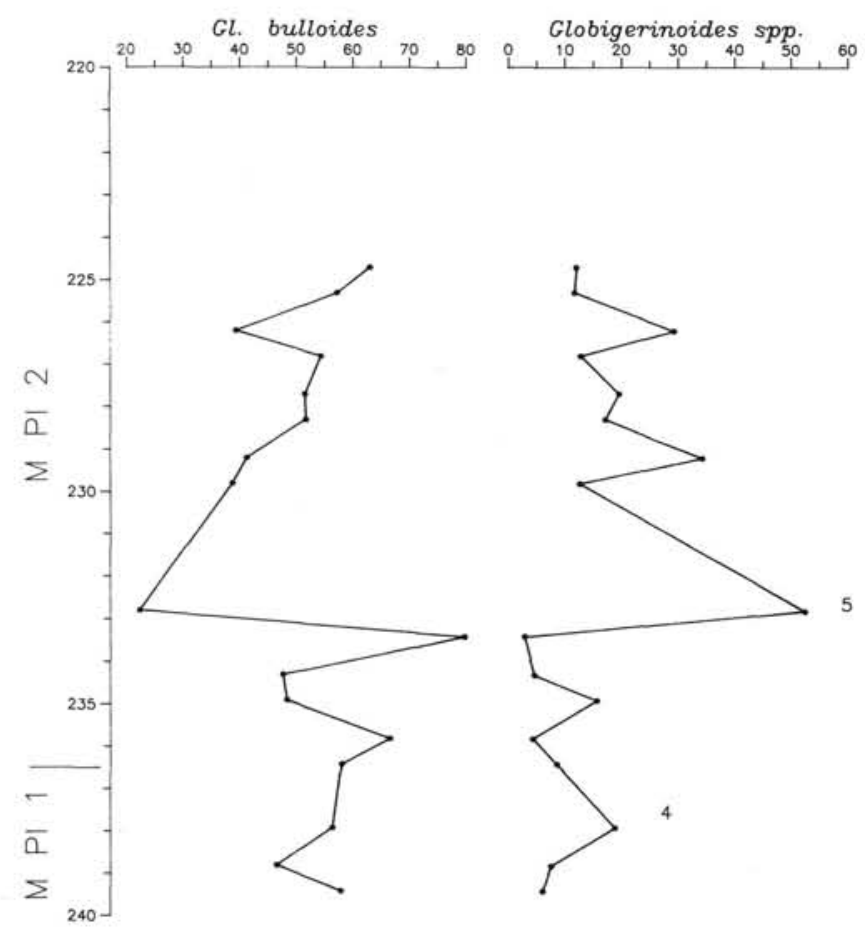

Figure 4. Graph for Hole 654A showing fluctuations with depth between warm-cold cycles, as indicated by changes in the relative percent of Globigerinoides spp. (warmer waters) vs. Globigerina bulloides (s.1.) (colder waters).

At Hole $654 \mathrm{~A}$, benthonic foraminifera are abundant beginning with the lowermost Pliocene sediments and percent data are significant. In the two basal cores (Cores 25R and 26R), 102 , often very rare, species were identified and the number of specimens per sample ranges between 78 and 256. Although the lowermost part of MPI1 is surely missing, the interval including the uppermost part of MPI1 coincident with the end of Sphaeroidinellopsis acme and the basal part of MPl2 contains common to abundant $U$. pygmaea $(13 \%-36 \%)$, which completely disappears above. Also in this interval, the following species occur but are rare to few: Astrononion stelligerum, Bigenerina nodosaris, and $O$. stellatus (which increase above); D. filiformis, Epistominella exigua, Nonionella sloani, and Pleurostomella alternans (which drastically decrease above); and $G$. subglobosa, Sphaeroidina bulloides, and Sigmoilinita tenuis (which decrease above). Bigenerina nodosaria, Parrelloides bradyi, $P$. robertsonianus, Cibicidoides(?) italicus, and Pullenia bulloides are consistently present beginning above this interval, while Siphonina reticulata strongly increases above this interval. The consistent presence of $G$. subglobosa and $U$. pygmaea in the interval between 238.0 and 229.8 mbsf (or the basal part of MPll zone) is considered indicative of a slightly oxygen-deficient environment. The fairly diversified and abundant benthonic assemblage suggests that the oxygen deficiency was relatively low. The entrance of species indicative of well-oxygenated waters above $229.8 \mathrm{mbsf}$ suggests that bottom conditions improved.

In general, at all three sites, the MPI1/MPI2 boundary, as recognized by the F.O. Globorotalia margaritae, is straddled by an interval showing a contemporaneous relative increase in $U$. pygmaea. The base of this interval is practically coincident with the end of the Sphaeroidinellopsis acme. Bottom waters during this interval were probably cold and depleted in oxygen, as suggested by the occurrence of $U$. pygmaea (or U. peregrina), which is considered to be an indicator of low-oxygen, cold bottom-water conditions (Lutze, 1978, 1979; Blanc-Vernet, 1983). Its con- sistent presence in the earliest Pliocene (MPl1 and basal MP12) sediments, regardless of whether the surface waters were warmer or colder, strongly suggests that the bottom waters were not affected by the interpreted climatic cycles. They remained cold and oxygen-deficient throughout this period.

\section{CHEMOSTRATIGRAPHY OF THE EARLIEST MEDITERRANEAN PLIOCENE}

\section{Percent Carbonate}

The carbonate content of the Trubi Formation at the stratotype Zanclean section in Sicily ranges between $56 \%$ and $80 \%$ with the highest values occurring in the basal Sphaeroidinellopsis acme interval (Cita and Gartner, 1973). Thus, the earliest Pliocene (MPl1) sediments can be characterized by their relatively high carbonate contents and \% carbonate stratigraphy can be useful as a method for correlating sections.

High resolution carbonate measurements were made for the basal Pliocene sediments at Site 652 and the $\%$ carbonate data are plotted against depth in Figure 5. The lowermost samples (188.1-186.5 mbsf) fluctuate widely between $32.1 \%$ and $55.5 \%$. Afterward, the values average $54.0 \pm 2.6 \%$ increasing slightly upsection to a maximum of $58 \%$ at $179.3 \mathrm{mbsf}$, which is $0.8 \mathrm{~m}$ below the top of the acme interval at 178.5 mbsf. Between 179.3 and $177.4 \mathrm{mbsf}$, the value steadily decreases to $42.9 \%$. This minimum occurs just prior to F.O. Globorotalia margaritae at $176.5 \mathrm{mbsf}$ and notably the MPl1/MPl2 boundary is afterward marked by a sharp increase in $\%$ carbonate.

The $\%$ carbonate stratigraphy for Hole 653B (Fig. 6) shows a maximum value of $70 \%$ at $212.5 \mathrm{mbsf}$, which is $1 \mathrm{~m}$ below the top of the Sphaeroidinellopsis acme at 211.5 mbsf. Subsequently, a minimum value of $45.2 \%$ is reached at $211.0 \mathrm{mbsf}$, followed by increasing values to $64.9 \%$ at $208.7 \mathrm{mbsf}$. As at Site 652 , the MPI1/MPI2 boundary ( 209.0 mbsf) occurs within this period of increasing values. A similar, but slightly offset, pattern is seen in the $\%$ carbonate data from Hole 654A (Fig. 7). From the base, a maximum value of $59.4 \%$ is reached at 237.5 mbsf, which is $1.3 \mathrm{~m}$ above the end of the acme. The minimum carbonate content of $46.7 \%$ is at $236.5-235.9$ mbsf, which correlates exactly with the F.O. Globorotalia margaritae at 236.4 mbsf.

In general, the carbonate content for the basal Pliocene of the three sites show high or increasing values throughout MPl1 zone. At the more stratigraphically complete Sites 652 and 653 , a maximum in \% carbonate is reached at the end of the Sphaeroidinellopsis acme, which is followed by a sharp decrease in $\%$ carbonate prior to the F.O. G. margaritae (i.e., the MPl1/MPl2 boundary). At Hole $654 \mathrm{~A}$, the sharp decrease in $\%$ carbonate occurs at the MPl1/MPl2 boundary. The lack of an exact correlation among the three sites may be a result of different sampling densities, but the approximate coincidence between carbonate fluctuations and biological markers does suggest that the paleoenvironmental changes producing the fluctuations were basin-wide.

\section{Stable Isotope Composition}

\section{Planktonic Foraminifera}

The more complete MPI1 section recovered at Site 652 provides an excellent stable-isotope record with which to evaluate paleoceanographic conditions in the Mediterranean directly following the reflooding. In Figure 5, the oxygen- and carbon-isotope values of the planktonic foraminifera ( $G$. obliquus) are plotted against depth. The most striking trend in the data is the consistent decrease in the $\delta^{18} \mathrm{O}$ value from $+1.36 \%$ at 187.2 mbsf to $-2.12 \%$ at 178.2 mbsf. The minimum value is coincident with the end of the Sphaeroidinellopsis acme at $178.5 \mathrm{mbsf}$ 

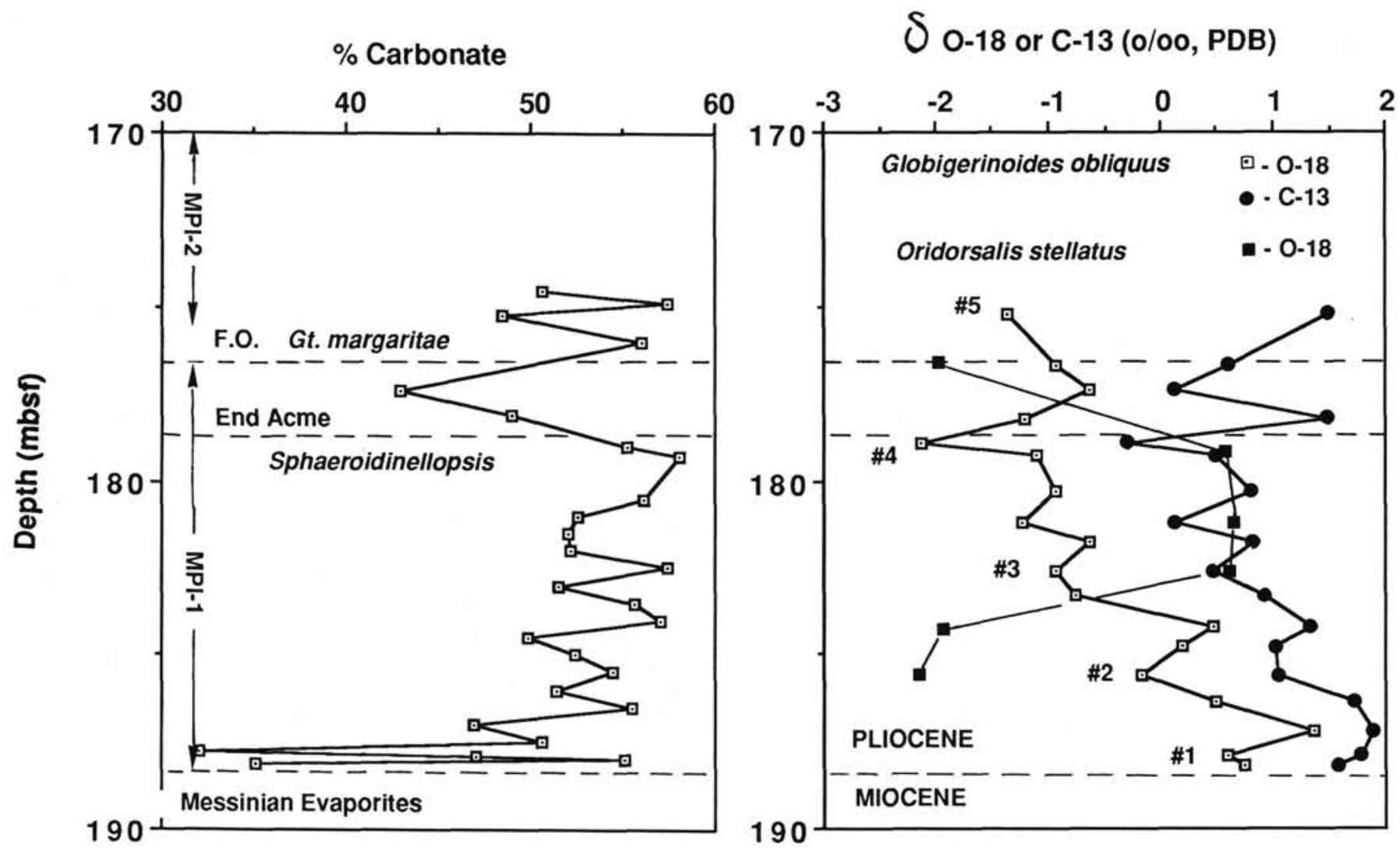

Figure 5. High-resolution chemostratigraphy for the earliest Pliocene at Hole 652A. The dashed lines correspond respectively to the placement of the Miocene/Pliocene boundary, the top of the Sphaeroidinellopsis acme interval, and the first occurrence of Globorotalia margaritae, which defines the MPI1/MPI2 boundary. The numbers alongside the oxygen-isotope curve signify the position of the relative increases in Globigerinoides spp. (Fig. 2) or warmer waters, as likewise suggested by the cycles of relative depletion in ${ }^{18} \mathrm{O}$. These depletions alternate with periods of relative enrichments corresponding to colder water intervals as indicated by greater abundance of Globigerina bulloides (s.l.). See discussion in text for paleoceanographic interpretations.

and less than $1 \mathrm{~m}$ above the carbonate maximum at $179.3 \mathrm{mbsf}$. Superimposed on the overall decrease of $3.5 \%$ are smaller scale fluctuations with magnitudes ranging between 0.5 and $1.5 \%$. The timing and direction of the small scale variations are consistent with the warm-cold cycles defined by the changes in relative abundance of planktonic foraminifera, i.e., negative isotope excursions correspond to warmer periods and positive isotope excursions with cooler periods. In Figure 5, the numbers (1-5) placed alongside the oxygen-isotope curve correspond to the stratigraphic position of the warmer periods defined by the foraminifera assemblage. The cooler foraminifera intervals would, thus, fall in between those designated numbers on the figure.

The isotope data for Holes 653B and 654A are plotted against depth in Figures 6 and 7, respectively. The data for the MPl1 zone are not as complete as those for Site 652. Also, the stratigraphic positions of the warmer periods denoted by the foraminiferal evaluations do not necessarily correspond to points of decreasing ${ }^{18} \mathrm{O}$ compositions. As the match was so clear for Site 652 , the lack of correspondence may be a reflection of an insufficient sampling density, as well as the incomplete recovery of the MP11 zone. On the other hand, the minimum $\delta^{18} \mathrm{O}$ value of $-2.40 \%$ at Site 654 occurs at 237.3 mbsf, stratigraphically close to the end of the Sphaeroidinellopsis acme at $238.8 \mathrm{mbsf}$ and coincident with the first maximum in the carbonate content at 237.5 mbsf.

The decrease in $\delta^{18} \mathrm{O}$ from +1.36 to $-2.12 \%$ at Site 652 may reflect a global climatic warming, i.e., the isotopic change results from a combination of a glacial eustatic sea level rise or ice volume effect in conjunction with a climatic warming around the Miocene/Pliocene boundary. In the late Pliocene at about $3.1 \mathrm{Ma}$, Grazzini et al. (this volume) recorded an increase in the $\delta^{18} \mathrm{O}$ value of $G$. obliquus with a range from -1.54 to $+0.67 \%$, which they interpreted as the result of a climatic cooling. As the range of these late Pliocene values falls within that measured for the early Pliocene at Site 652, the magnitude of the latter change is apparently not unusual for the Tyrrhenian Sea. Therefore, a possible explanation for the isotopic trend in the earliest Pliocene is that a global warming resulted in the melting of continental glaciers and lead to an inflow of increasingly, isotopically lighter Atlantic water to the Mediterranean.

The carbon-isotope data acquired for the planktonic samples are plotted alongside the corresponding oxygen-isotope data in Figures 5, 6, and 7. At Site 652 (Fig. 5), the oxygen- and carbon-isotope values show covariance from the basal Pliocene up to 178.9 mbsf, which corresponds to the end of the Sphaeroidinellopsis acme at 178.5 mbsf. Above this level, the isotope values tend to fluctuate in opposite directions from each other. The distinctive isotopic covariance within the Sphaeroidinellopsis acme interval can be seen in a cross-plot of the $\delta^{13} \mathrm{C}$ vs. $\delta^{18} \mathrm{O}$ values of $G$. obliquus (Fig. 8). A linear regression curve fitted to the points has a correlation coefficient of 0.96 . The factors producing the covariance are a matter of speculation. The slope of the curve $(0.6437)$ is too great to be solely caused by an overall temperature increase. The temperature dependency of carbonisotope fractionation is approximately $0.035 \% 0 /{ }^{\circ} \mathrm{C}$ (Emrich et al., 1970), while for oxygen it is approximately $0.2 \%{ }^{\circ} \mathrm{C}(\mathrm{Ep}-$ 
$\%$ Carbonate

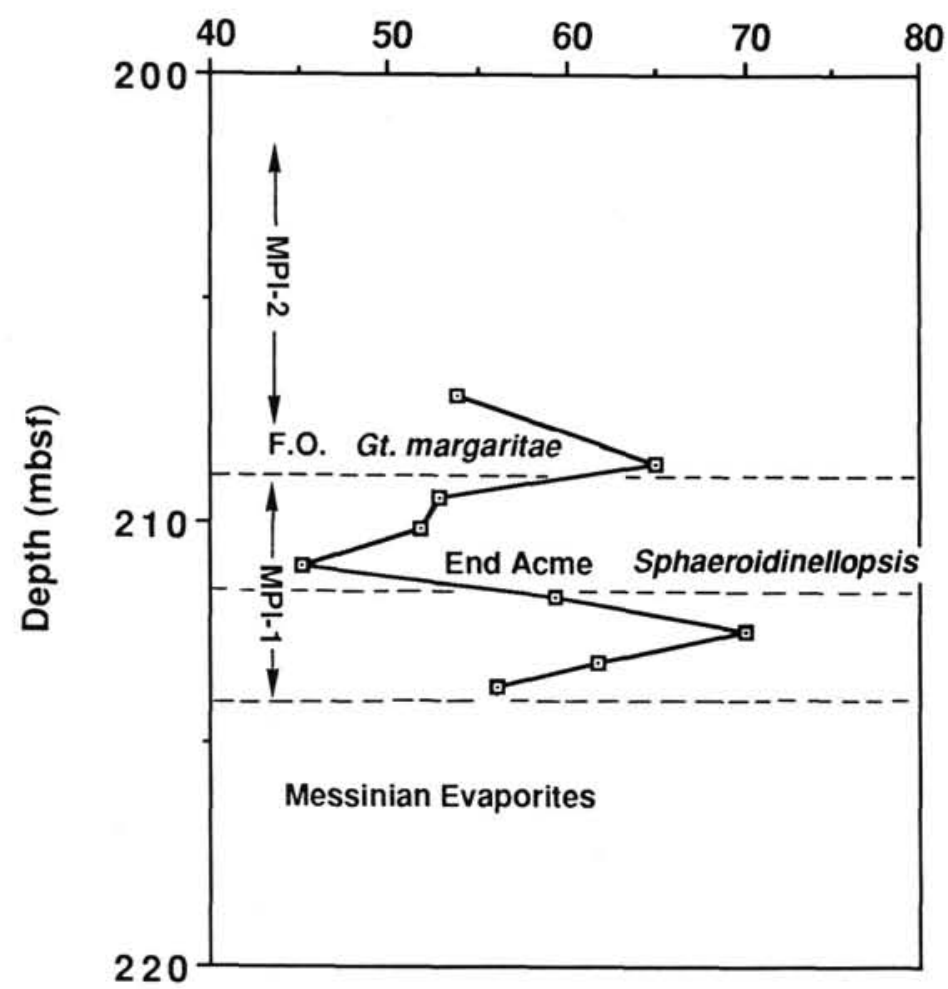

ठ $0-18$ or $\mathrm{C}-13(0 / 00, \mathrm{PDB})$

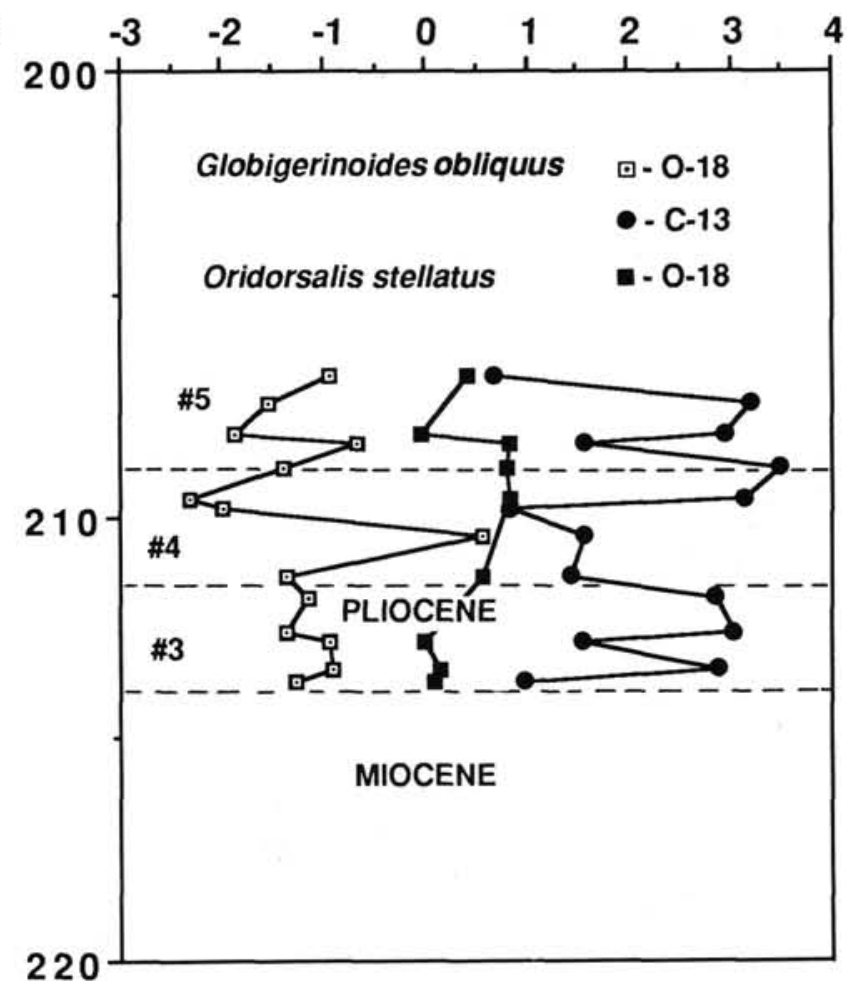

Figure 6. High-resolution chemostratigraphy for the earliest Pliocene at Hole 653B. The dashed lines correspond respectively to the placement of the Miocene/Pliocene boundary, the top of the Sphaeroidinellopsis acme interval and the first occurrence of Globorotalia margaritae, which defines the MPl1/MP12 boundary. The numbers alongside the oxygen-isotope curve signify the position of the relative increases in Globigerinoides spp. (Fig. 3). See discussion in text for paleoceanographic interpretations.

stein el al., 1953). The slope of a purely temperature-dependent curve would, thus, be 0.175 . One possibility is that the covariance results from evaporation, a process which may enrich the ${ }^{18} \mathrm{O}$ content of the surface waters at a greater rate than the ${ }^{13} \mathrm{C}$ content. Relatively intense evaporation of a smaller water body, which may have existed with the onset of flooding in the earliest Pliocene, could have produced water isotopically heavier in both oxygen and carbon than the marine input. Throughout the acme interval with continued infilling, the effects of evaporation decrease as the size of the water body increases and an isotopically lighter water mass becomes more and more the dominant in the Tyrrhenian Sea. In conclusion, a global warming in the early Pliocene in combination with decreasing evaporation effects on a ever deeper water body could have produced the observed isotopic curve. The changeover from isotopic covariance to non-covariance at the end of the Sphaeroidinellopsis acme may denote a significant change in paleoceanography or paleoenvironmental conditions.

At Hole 653B, the data available for the acme interval are limited, and a covariance is not particularly obvious (Fig. 6). On the other hand, a striking, non-covariant trend is seen in the post-acme data. The data from Hole 654A (Fig. 7) show no significant trends.

\section{Benthonic Foraminifera}

As the earliest Pliocene sediments contain relatively few benthonic foraminifera, an extensive isotopic analysis of monospecific assemblages was difficult to preform and awaits further study. From Site 652 sufficient specimens of $O$. stellatus were available in six samples, and the results of the oxygen-isotope analysis are plotted in Figure 5. Interestingly, in the earliest Pliocene (185.6-184.2 mbsf), the data suggest that the bottom waters were either isotopically lighter than the surface waters or, perhaps, warmer by about $10^{\circ}-12^{\circ} \mathrm{C}$, a very abnormal marine condition. In either case, the water body must have been stratified to produce such an unusual situation. Between 182.6 and 179.3 mbsf, the remainder of the Sphaeroidinellopsis acme interval, the oxygen-isotope values suggest a more normal situation with the benthonic foraminifera being isotopically heavier than the surface waters dwellers. If the difference were purely a temperature phenomenon, the bottom waters would be approximately $8^{\circ}-9^{\circ} \mathrm{C}$ cooler than the surface waters, not unlike the modern Tyrrhenian Sea. The uppermost analysis at $176.7 \mathrm{mbsf}$, coincident with the F.O. G. margaritae, shows again a return to unusual conditions with an isotopically lighter value occurring in the benthos.

The carbon-isotope gradient between planktonic and benthonic foraminifera is frequently used as a monitor of water conditions. In general, under normal marine conditions, the surface waters are enriched in ${ }^{13} \mathrm{C}$ relative to the bottom waters, as a result of photosynthesis and respiration processes. At Site 652 , the $\delta^{13} \mathrm{C}$ values of the planktonic foraminifera range between -0.29 and $1.89 \%$, consistently more positive than the values for the benthonic foraminifera $(-4.81$ to $-1.77 \%)$. The surface-to-bottom, carbon-isotope gradient is about $5.5 \%$ between 185.6 and $184.2 \mathrm{mbsf}, 2.6 \%$ between 182.6 and 179.3 mbsf and $4.2 \%$ at $176.6 \mathrm{mbsf}$. In other words, during the periods with the abnormal oxygen-isotope gradients, there is a significant increase in the carbon-isotope gradient, primarily as a result of relatively greater ${ }^{13} \mathrm{C}$ depletion in the benthonics. This 
$\%$ Carbonate

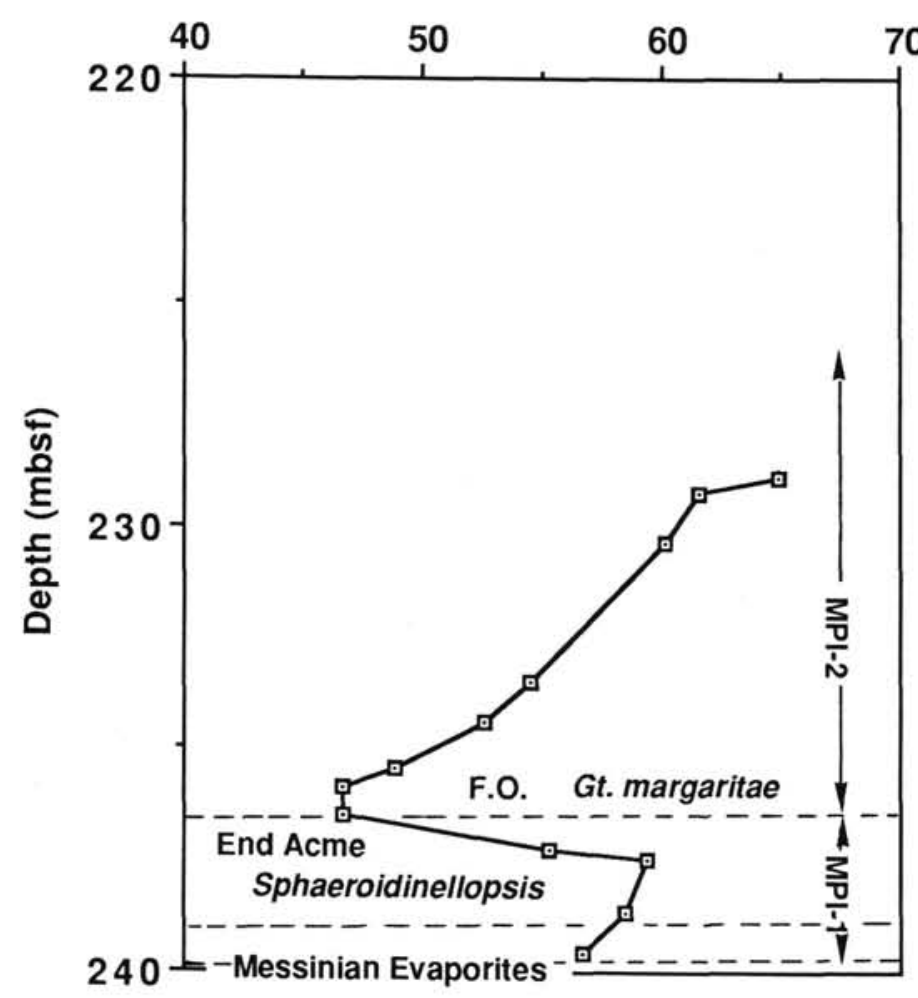

S $0-18$ or $\mathrm{C}-13(0 / 00, \mathrm{PDB})$

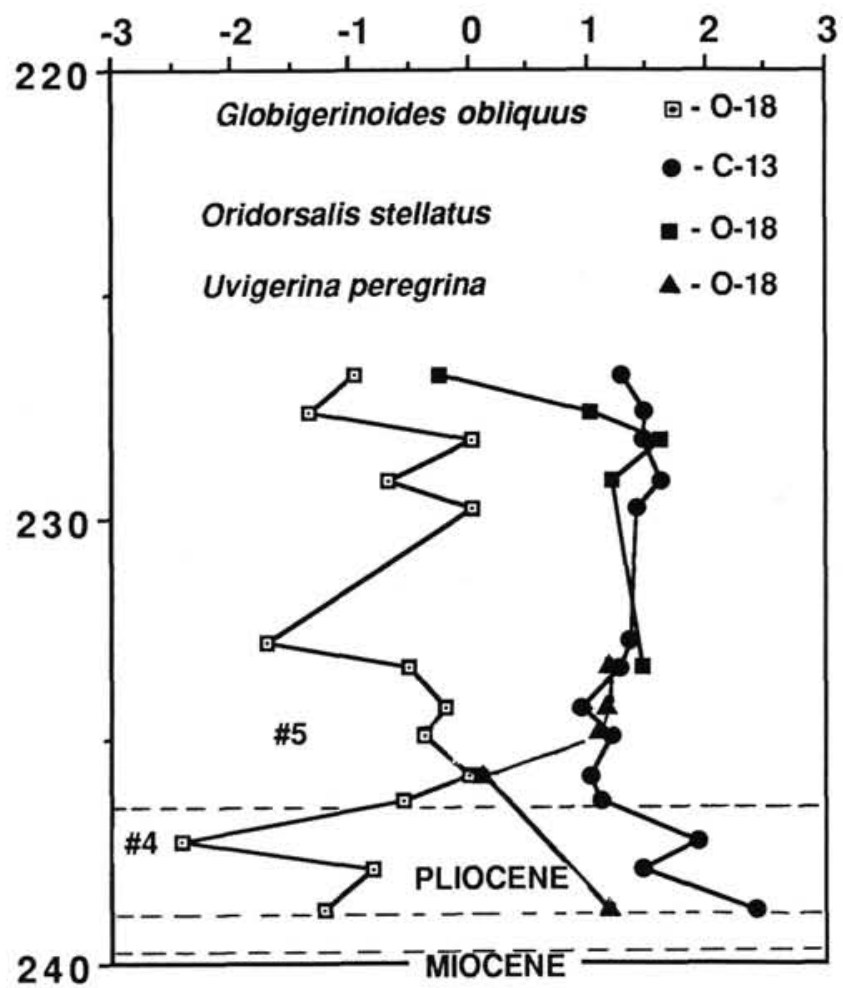

Figure 7. High-resolution chemostratigraphy for the earliest Pliocene at Hole 654A. The dashed lines correspond respectively to the placement of the Miocene/Pliocene boundary, the top of the Sphaeroidinellopsis acme interval and the first occurrence of Globorotalia margaritae, which defines the MPI1/MP12 boundary. The numbers alongside the oxygen-isotope curve signify the position of the relative increases in Globigerinoides spp. (Fig. 4). See discussion in text for paleoceanographic interpretations.

\section{ODP SITE 652: ISOTOPIC COVARIANCE}

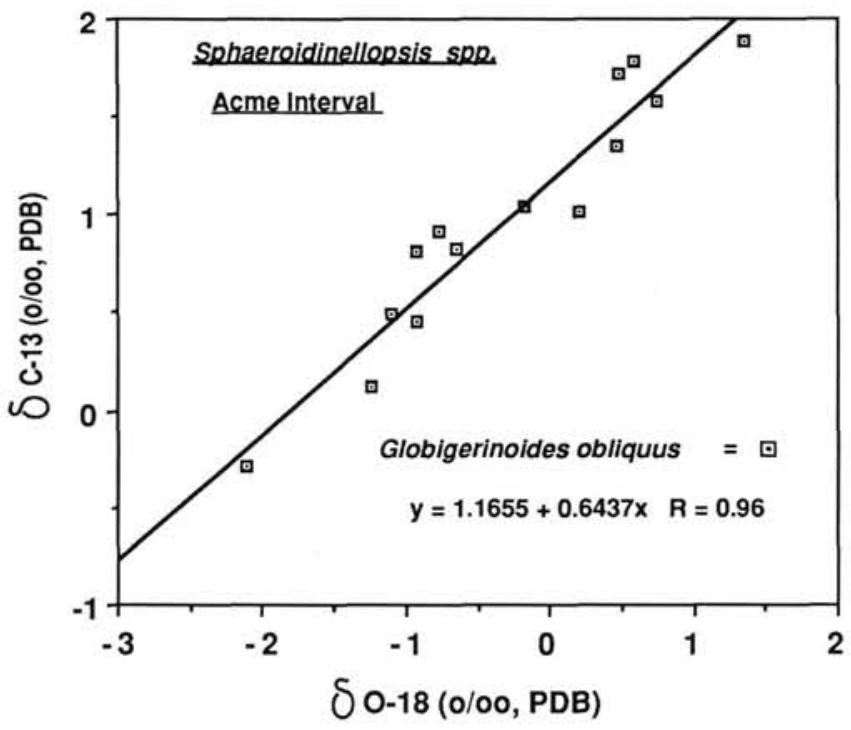

Figure 8. Cross-plot of oxygen- and carbon-isotope values of the planktonic foraminifera analyzed exclusively from the Sphaeroidinellopsis acme interval at Site 652 . The covariance shown by the excellent correlation of the linear regression fit suggests that a similar mechanism may have controlled the fractionation of both isotopes. See text for discussion. may be a reflection of relatively more respiration in the bottom waters or the introduction of a water mass with an isotopic composition different from the surface waters, as suggested by both sets of isotope data. As there were not sufficient benthonic specimens in each sample to perform duplicate isotopic analysis, a more definitive evaluation of the unusual benthonic isotope values awaits further sampling and analyses.

For Hole 653B, nine samples of $O$. stellatus from the base of the earliest recovered Pliocene into the basal MPI2 zone were picked and measured (Fig. 6). Here, the benthonic foraminifera remained enriched in ${ }^{18} \mathrm{O}$ relative to the planktonics, indicating that bottom waters were $7^{\circ}-8^{\circ} \mathrm{C}$ cooler than surface waters. The $\delta^{18} \mathrm{O}$ values showed little variation throughout the measured interval The carbon-isotope values for the benthonic samples are consistently depleted in ${ }^{13} \mathrm{C}$ relative to the co-existing planktonics, which suggests that a normal surface-to-bottom, carbonisotope gradient existed. The benthonic data from Hole 653B are basically consistent with those datum points from Site 652 which record normal surface-to-bottom water isotope gradients.

For Hole 654A, $U$. peregina was measured from samples which correlate with the end of the Sphaeroidinellopsis acme and across the MP11/MPI2 boundary (Fig. 7). Just above the boundary, the data suggest that the oxygen isotope gradient broke down. This event occurs in a sample which also exhibited a $\%$ carbonate minimum. A similar geochemical pattern in both $\%$ carbonate and $\delta^{18} \mathrm{O}$ was recorded at Site 652 at this same boundary. As the recognized F.O. G. margaritae may be slightly offset between sites, it is proposed that the geochemical event is the same at both sites. At Hole $654 \mathrm{~A}, \delta^{18} \mathrm{O}$ measure- 
ments of $U$. peregrina and $O$. stellatus from the overlying sediments suggest that the isotopic gradient was soon after reestablished.

\section{DISCUSSION OF RESULTS}

A scenario for paleoceanographic conditions in the Tyrrhenian Sea following the earliest Pliocene marine flooding evolves out of the combined bio- and chemostratigraphic information obtained from the more complete section recovered at Site 652 . It is possible to place the sequence of events into an approximate time framework. Based on the shipboard magnetostratigraphic data, the top of the Thvera (C2) occurs at $167.2 \mathrm{mbsf}$ (Shipboard Scientific Party, 1987a) and has a age of $4.57 \mathrm{Ma}$ (Berggren et al., 1985)). Assuming a strontium-isotope age for the Miocene/Pliocene boundary of 4.9 Ma (McKenzie et al., 1988), the sedimentation rate would be $5.5 \mathrm{~cm} / 1,000$ yr between the earliest Pliocene at $188.1 \mathrm{mbsf}$ and the top of the Thvera. Assuming that this sedimentation rate is constant, it can be used to estimate the timing of the bio- and chemostratigraphic events relative to the initial marine flooding.

The first sediments immediately after the flooding are barren of benthonic foraminifera. The carbonate content of these earliest sediments tends to fluctuate broadly between $30 \%$ and $60 \%$, suggesting very unstable conditions. At about 30,000 yr postflood, the carbonate content stabilizes in the range of $50 \%$ $60 \%$. Bottom-water conditions apparently became suitable for some benthonic activity as demonstrated by the appearance of $O$. stellatus in the sediments. Two additional benthonic foraminifera ( $G$. subglobosa and $G$. neosoldanii) joined the assemblage at about 50,000 yr post-flood but disappear with the end of the Sphaeroidinellopsis acme.

In the very earliest Pliocene, the difference in the isotopic composition of the benthonic and planktonic fauna suggest that there may have been two stratified water masses with distinctly different isotopic values. A more normal, surface-to-bottom, oxygen-isotope gradient was established at about $80,000 \mathrm{yr}$ postflood and continued until the end of the acme. The oxygen-isotope values suggest that the earlier distinction between the two water masses disappeared and bottom-water temperatures were approximately $8^{\circ} \mathrm{C}$ cooler than surface waters.

Throughout the Sphaeroidinellopsis acme interval, the oxygen- and carbon-isotope compositions of the planktonic foraminifera show a remarkable covariance, which could indicate that both isotopes experienced a common fractionation mechanism. This observation, together with the overall trend toward isotopically lighter surface waters, suggests that the observed covariance could have been achieved by a decreasing amount of evaporation in an increasingly larger water body as the Tyrrhenian Sea infilled after the initial flooding. The magnitude of the overall isotopic decrease $\left(\Delta \delta^{18} \mathrm{O}=3.4 \%\right.$ ) could have been accentuated by a simultaneous global warming (or ice volume effect).

Superimposed on the overall trend toward isotopically lighter waters are smaller scale warm-cold cycles identified by changes in the planktonic foraminiferal assemblage, which are consistent with the isotopic fluctuations. As mentioned above, these cycles are on a time scale similar to Quaternary Milankovitch cycles. The fact that these cycles emerge from the data confirms the potential for high-resolution stratigraphy in essentially undisturbed cores. A further interpretation of these short-term cycles is that orbitally forced, climate cycles occurred during the early Pliocene but were not the direct cause of the transgressive infilling of the Mediterranean. This interpretation of the data from Site 652 suggests that the Sphaeroidinellopsis acme interval represents the infilling period after the onset of flooding conditions. During this period, stable conditions conducive to a faunal acme were maintained throughout.
The abrupt end of the Sphaeroidinellopsis acme interval at approximately $180,000 \mathrm{yr}$ post-flood is marked by a break-down of the previously established oceanographic conditions. This is denoted by a drastic decrease in the carbonate content of the sediments and a return to abnormal surface-to-bottom, oxygenisotope gradient. There is an apparent cooling of the surface waters based on the planktonic assemblage and a swing toward more positive oxygen-isotope values, while, at the same time, the bottom waters appear to be isotopically lighter than the surface waters. Coincident with these changes, the strict oxygenand carbon-isotope covariance ceases, and the data afterward tend to be invariant. Also, U. pygmaea, considered to be an indicator for low-oxygenated, cold bottom-water conditions, appears in the sediments. Thus, the bio- and chemostratigraphic changes at the end of the acme appear to signify a significant change in oceanographic conditions.

The collapse of the Gibraltar sill and the inflow of colder, deeper Atlantic waters, as proposed earlier by Cita and Ryan (1973), could be the mechanism for achieving this relatively sudden change in conditions. Benson (1973) proposed that the occurrence of psychrospheric ostracodes in early Pliocene Mediterranean deep-sea sediments was strong evidence for an influx of cold, deep Atlantic waters. Similar ostracodes are found today only at depths in the Atlantic greater than $1500 \mathrm{~m}$ and at temperatures less than $6^{\circ} \mathrm{C}$. As they could not pass through a warm-water temperature barrier, the establishment of psychrospheric ostracodes in the early Pliocene Mediterranean would require a cold water connection between the two water bodies. Psychrospheric ostracodes were not recognized in MPll or basal MP12 sediments of the studied sites (Sprovieri et al., this volume). Their absence suggests that conditions were unfavorable for their entrance into the Tyrrhenian Sea during the earliest Pliocene, which supports the proposal that the deep-water connection to the Atlantic opened sometime after the initial flooding.

With the migrational first occurrence of $G$. margaritae at about 200,000 yr post-flood, which defines the MPl1/MPl2 boundary, new paleoceanographic conditions were established. The carbonate content of the sediments again increased, while the bottom waters remained deficient in oxygen, as indicated by the presence of $U$. pygmaea, suggesting sluggish circulation. At about $250,000 \mathrm{yr}$ post-flood, the presence of a "deep" Atlantic benthonic foraminiferal assemblage indicates that the bottom waters contained normal oxygen levels and a more dynamic circulation existed within the Tyrrhenian Sea.

\section{CONCLUSIONS}

In summary, the detailed stratigraphy in the earliest Pliocene sediments at Site 652 , which contain the best preserved and most complete MPl1 zone available to date, indicates that the paleoceanographic conditions following the earliest Pliocene flooding of the Tyrrhenian Sea can be divided into two periods separated by a catastrophic event. The first period is represented by Sphaeroidinellopsis acme interval, which was the time of gradual infilling of the Mediterranean and establishment of oceanographic continuity with the Atlantic surface waters. By the end of this period, oceanographic conditions signifying normal surface-to-bottom gradients were present. Between the end of the Sphaeroidinellopsis acme and the F.O. G. margaritae, there was a breakdown in the oceanographic conditions, as a result of the collapse of the Gibraltar sill, allowing for the influx of cold, deep Atlantic into the Mediterranean. Normal oceanographic conditions were once again re-established in the early part of the MPI2 zone.

The twofold event stratigraphy within the MPIl zone, a period of about $200,00 \mathrm{yr}$, occurs at the onset of a major, eustatic sea level rise in the early Pliocene (Haq et al., 1986). The onset of this rise, as seen in the deep-sea oxygen isotope record at 
DSDP Site 519 in the South Atlantic (McKenzie and Oberhansli, 1985) began prior to the transgressive reflooding of the Mediterranean Sea, based on the strontium-isotope age of Miocene/Pliocene boundary determined at the boundary stratotype in Sicily (McKenzie et al., 1988). A general climatic warming associated with a steady eustatic sea level rise continued until about 4.3 $\mathrm{Ma}$, producing the last major transgression prior to the overall regressive phases of the Pliocene-Pleistocene glaciations (Haq et al., 1986).

It is proposed that this steady rise in sea level was a prime factor causing the catastrophic flooding of the Mediterranean and bringing to an end the Messinian salinity crisis. Lithologically, the end of the evaporite Messinian is marked by cyclic episodes of evaporite deposition alternating with periodic marine influxes (e.g., Shipboard Scientific Party, 1987c). Obviously, the negative hydrologic balance in the Mediterranean was sufficient to maintain extreme evaporitic conditions even while small fluxes of seawater flowed into the Mediterranean. The mechanism required to push the system out of the evaporative mode was the earliest Pliocene, eustatic sea level rise. The resultant transgressive, steady infilling of the Mediterranean can be read in the oxygen-isotope record of the Sphaeroidinellopsis acme interval. The catastrophic collapse of oceanographic conditions at the end of the acme may be the result of a tectonic break in the flood-eroded, Gibraltar sill, which allowed deep, cold Atlantic waters to spill into the Mediterranean. In the end, a combination of eustatic sea level rise and tectonic movements resulted in the full restoration of normal marine conditions in the Mediterranean, but only approximately $250,000 \mathrm{yr}$ after the initiation of the earliest Pliocene marine flooding.

\section{ACKNOWLEDGMENTS}

We would like to acknowledge P. K. Swart and his colleagues for their generous assistance and access to the facilities of the Stable Isotope Laboratory at RSMAS, University of Miami. We also thank T. Sunday for the $\%$ carbonate measurements and $\mathrm{M}$. Brenner for access to equipment housed in the Florida State Museum, University of Florida. We would further wish to acknowledge $C$. Vergnaud Grazzini for thoughtful discussions and two anonymous reviewers for constructive comments. This research was partially supported by an USSAC Grant \#86032118 to J. A. McKenzie and Italian CNR Grant 87.00887.05 to R. Sprovieri.

\section{REFERENCES}

Benson, R. H., 1973. Psychrospheric and continental ostracoda from ancient sediments in the floor of the Mediterranean. In Ryan, W.B.F., Hsü, K. J., et al., Init. Repts. DSDP, 13: Washington (U.S. Govt. Printing Office), 1002-1008.

Berggren, W. A., Kent, D. V., and VanCouvering, J. A., 1985. Neogene chronology and chronostratigraphy., In Snelling, N.J., (Ed.), The Geochronology of the Geologic Record, Geol. Soc. Lond. Memoir, 10:211-260.

Blanc-Vernet, L., 1983. Benthic foraminifers of Site 533, Leg 76 of the Deep Sea Drilling Project-faunal variations during the Pliocene and Pleistocene on the Blake outer ridge (western North Atlantic).
In Sheridan, R. E., Gradstein, F. M., et al., Init. Repts. DSDP, 76: Washington (U.S. Govt. Printing Office), 497-509.

Broecker, W. S., Thurber, D. L. Goddard, J., Ku, T. L., Matthews, R. K., and Mesolella, K. J., 1968. Milankovitch hypothesis supported by precise dating of coral reefs and deep-sea sediments. Science 159: 297-300.

Cita, M. B., and Gartner, S., 1973. Studi sul Pliocene e sugli strati di passaggio dal Miocene al Pliocene IV. The stratotype Zanclean foraminiferal and nannofossil biostratigraphy. Riv. It. Paleontol., 79: 503-558.

Cita, M. B., and Ryan, W.B.F., 1973. Time scale and general synthesis. In Ryan, W.B.F., Hsü, K. J., et al., Init. Repts. DSDP, 13: Washington (U.S. Govt. Printing Office), 1405-1415.

Craig, H., 1957. Isotopic standards for carbon and oxygen and correction factors for mass-spectrometric analysis of carbon dioxide. Geochim. Cosmochim. Acta, 12:133-149.

Emrich, K., Ehhalt, D. H., and Vogel, J. C., 1970. Carbon isotope fractionation during the precipitation of calcium carbonate. Earth Planet. Sci. Lett., 8:63-371.

Epstein, L. S., Buchsbaum, R., Lowenstam, H. A., and Urey, H. C., 1953. Revised carbonate water isotopic temperature scale. Geol. Soc. Am. Bull., 64:1315-1326.

Haq, B. U., Hardenbol, J., and Vail, P. R., 1988. Chronology of fluctuating sea levels since the Triassic ( 250 million years ago to present). Science, 235:1165-1167.

Lutze, G. F., 1978, Neogene benthonic foraminifera from Site 369, Leg 41, Deep Sea Drilling Project. In Lancelot, Y., Seibold, E., et al., Init. Repts. DSDP, 41: Washington (U.S. Govt. Printing Office), 659-666.

1979. Benthic foraminifers at Site 397: Faunal fluctuations and ranges in the Quaternary. In von Rad, U., Ryan, W.B.F, et al., Init. Repts. DSDP, 47: Washington (U.S. Govt. Printing Office), 419-431.

McCrea, J. M., 1950. The isotopic chemistry of carbonates and a paleotemperature scale. J. Chem. Phys., 18:849-857.

McKenzie, J. A., Hodell, D. A., Mueller, P. A., and Muller, D. W., 1988. Application of strontium isotopes to late Miocene-early Pliocene stratigraphy. Geology, 16:1022-1025.

McKenzie, J. A., and Oberhansli, H., 1985. Paleoceanographic expressions of the Messinian salinity crisis. In Hsü, K. J., and Weissert, H. J. (Eds.), South Atlantic Paleoceanography: Cambridge (Cambridge Univ. Press), 99-123.

Shipboard Scientific Party, 1987a. Site 652. In Kastens, K. A., Mascle, J., et al., Proc. ODP, Init. Repts., 107: College Station, TX (Ocean Drilling Program), 403-597.

1987b. Site 653. In Kastens, K. A., Mascle, J., et al., Proc. ODP, Init. Repts., 107: College Station, TX (Ocean Drilling Program), 599-745.

1987c. Site 654. In Kastens, K. A., Mascle, J., et al., Proc. ODP, Init. Repts., 107: College Station, TX (Ocean Drilling Program), 747-875.

Wachter, E. A., and Hayes, J. M., 1985. Exchange of oxygen isotopes in carbon dioxide-phosphoric acid systems. Chem. Geol., 52:365-374.

Date of initial receipt: 10 March 1988

Date of acceptance: 27 January 1989

Ms 107B-162 